\title{
Jamaica Kincaid's Lucy as a Narrative of Exile and Identity
}

\author{
Sayed Mohammed Youssef \\ Department of English Language and Literature, College of Languages and Translation, \\ Al-Imam Muhammad Ibn Saud Islamic University \\ Riyadh, Kingdom of Saudi Arabia
}

\begin{abstract}
:
Jamaica Kincaid's novel Lucy is an artist novel whose eponymous protagonist breaks away from such forces as colonial and patriarchal mores, which eventually contributes to her construction of her own hybrid identity and inaugurates her maturity. This struggle is established perfectly well through Lucy's apparent resistance to the constraints primarily imposed on her race and gender at home by both her mother and the Eurocentric society on the one hand and the androcentric and racist society she encounters in diaspora on the other hand. Surprisingly enough, Lucy, who is chastened towards the end of the book, creates her rite of passage towards development and independence through her valiant efforts to overcome such confines at any cost. The aim of the present article is to analyse from a postcolonial perspective the protagonist's quest for identity in diaspora, the obstacles she overcomes to do so and to what extent she is affected by her new culture. This is manifested through intertwining discussions of androcentrism, colonial and postcolonial rebellion with questions of identity, hybridity, diaspora and cultural displacement. Key Words: Androcentrism, diaspora, hybridity, migration, patriarchy
\end{abstract}

Cite as: Youssef, M. Y. (2017). Jamaica Kincaid's Lucy as a Narrative of Exile and Identity. Arab World English Journal for Translation \& Literary Studies, 1(2).

DOI:http://dx.doi.org/10.24093/awejtls/vol1no2.5 